\title{
Climate change impacts on drought-prone forests in western Canada
}

\author{
by E.H. (Ted) Hogg ${ }^{1}$ and Pierre Y. Bernier ${ }^{2}$
}

\begin{abstract}
From a climate change perspective, much of the recent international focus on forests has been on their role in taking up carbon dioxide $\left(\mathrm{CO}_{2}\right)$ from the atmosphere. The question of climate change impacts on forest productivity is also emerging as a critical issue, especially in drought-prone regions such as the western Canadian interior. Because of the complexity of interacting factors, there is uncertainty even in predicting the direction of change in the productivity of Canada's forests as a whole over the next century. In the most climatically vulnerable regions, however, successful adaptation may require more innovative approaches to forest management, coupled with an enhanced capacity for early detection of large-scale changes in forest productivity, dieback and regeneration.
\end{abstract}

Key words: climate change, boreal forest, productivity, drought, impacts, adaptation

\section{RÉSUMÉ}

Dans le cadre des changements climatiques, la majeure partie de l'attention internationale récente sur les forêts a porté sur leurs rôles d'emmagasiner le dioxyde de carbone $\left(\mathrm{CO}_{2}\right)$ en provenance de l'atmosphère. La question des effets des changements climatiques sur la productivité forestière constitue également un enjeu majeur, surtout dans les régions sujettes à la sécheresse comme la partie intérieure de l'Ouest canadien. À cause de la complexité des facteurs en interaction, il existe une incertitude même dans la prédiction de la direction des changements dans la productivité des forêts canadiennes dans son ensemble au cours du prochain siècle. Dans le cas des régions les plus susceptibles en terme climatique, une adaptation réussie pourrait nécessiter des approches plus innovatrices en matière d'aménagement forestier, associées à une capacité accrue de détection hâtive des changements à grandes échelles dans la productivité forestières, le dépérissement et la régénération.

Mots clés : changements climatiques, forêt boréale, productivité, sécheresse, effets, adaptation

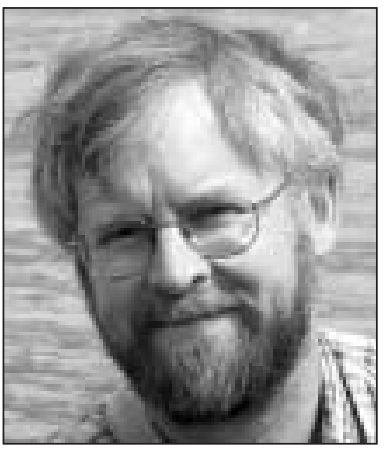

E.H. (Ted) Hogg

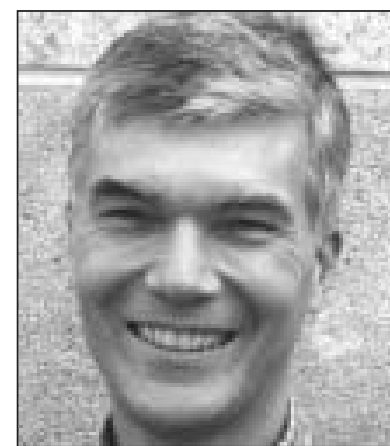

Pierre Y. Bernier

\section{Introduction}

The earth's climate is expected to warm by an average of $1.4^{\circ}$ to $5.8^{\circ} \mathrm{C}$ during this century, mainly because of humancaused increases in the levels of $\mathrm{CO}_{2}$ and other greenhouse gases in the atmosphere (Houghton et al. 2001). There is growing evidence that significant global warming is already underway. According to the US National Climatic Data Center (2005), the five warmest years on record to date were 1998, 2002, 2003, 2004 and 2001, when average global land temperatures were about $0.8-1.0^{\circ} \mathrm{C}$ above the long-term normal since 1880 . The rate of warming has been even greater in northern, continental regions such as the western Canadian boreal forest, where temperatures have increased nearly $2^{\circ} \mathrm{C}$ since the late 1940s (Environment Canada 2004). This warming trend has led to a rapid thawing of permafrost (Camill 2005), along with a recent tendency for shorter periods of winter road access into remote, forested areas.

One of the major challenges for the future management and conservation of forests in this region is that continued warming is expected to lead to drier conditions and more severe droughts in the future. Such changes would likely lead to an increase in the area of forests affected by natural disturbances, notably fire and insects (Volney and Hirsch 2005). Equally important, however, is the potential for direct impacts of climate change on forest productivity, health and regeneration. This issue is emerging as a critical concern, especially across western Canada where record dry conditions

\footnotetext{
${ }^{1}$ Natural Resources Canada, Canadian Forest Service, Northern Forestry Centre, 5320-122 Street, Edmonton, Alberta T6H 3S5. E-mail: thogg@nrcan.gc.ca (corresponding author)

${ }^{2}$ Natural Resources Canada, Canadian Forest Service, Laurentian Forestry Centre, C.P. 3800, Ste-Foy, Quebec G1V 4C7. E-mail: pbernier@rncan.gc.ca
} 
during 2001-2003 have led to widespread forest dieback and mortality (Hogg et al. 2005). Several reviews have been conducted on the topic of climate change impacts on the forest sector at the global scale (e.g., McCarthy et al. 2001) and within specific regions of North America (e.g., Papadopol 2000, Shugart et al. 2003). The Canada Country Study provided regional and national reviews on the potential impacts of climate change and variability on several sectors of Canadian society, including the forest sector (e.g., Saporta et al. 1998). The present paper focuses more specifically on the climate change impacts that may be already be leading to large-scale changes in the western Canadian interior.

The objectives of this paper are 1) to provide an overview of the global science issues relating to forests and climate change, 2) to examine the main climatic factors affecting forest growth and ecosystem functioning in the western Canadian interior, 3 ) to apply a simple model for identifying the most climatically sensitive areas, and 4) to present some preliminary forest management options that might be considered for adapting to the projected climatic changes in this region over the next few decades.

\section{Forests And Climate Change: The Major Science Issues}

Two major science issues can be identified under the general topic of forests and climate change. The first issue concerns the role of forests in global cycles of carbon, water and energy. This includes the question of how much carbon dioxide $\left(\mathrm{CO}_{2}\right)$ is absorbed or released by the world's forests, including the effects of forest management and land use changes on the earth's carbon cycle, which can ultimately influence the rate of long-term global warming. Internationally, much of the forest-related climate change research to date has been focused on this general question (e.g., Kurz and Apps 1999, Caspersen et al. 2000) because of its relevance to the attainment of $\mathrm{CO}_{2}$ emission targets set out under the Kyoto Protocol (Watson et al. 2000). A related question is the effect of forests on regional weather and climate. In northern areas, the presence of coniferous forests on snow-covered landscapes leads to warmer air temperatures during late winter and spring, as they absorb much more of the sun's energy compared to the surrounding white, treeless areas. In fact, this albedo effect could significantly decrease the benefit of afforestation of treeless lands for climate change mitigation (Betts 2000). On the other hand, deciduous forests such as aspen can act as "giant green humidifiers" after spring leaf-out, as they release large amounts of water vapour into the atmosphere, cooling the air and triggering more summer rainfall in continental areas (Hogg et al. 2000). Increasingly, these effects are being included in the newer versions of global climate models, because they could be just as important as rising $\mathrm{CO}_{2}$ levels in determining the rate of future climate change in response to changes in vegetation and land use (Pielke et al. 1998).

The second major science issue, that forms the main focus of the present paper, is the potential impact of climate change on forest growth and ecosystem functioning, including natural disturbances such as forest fire, insects and diseases. Despite scientific and technological advances in simulation modelling and remote sensing, great uncertainty remains even in predicting the direction of change in the potential productivity of the world's northern forests. Part of this

\section{Northern forest productivity under global climate change}

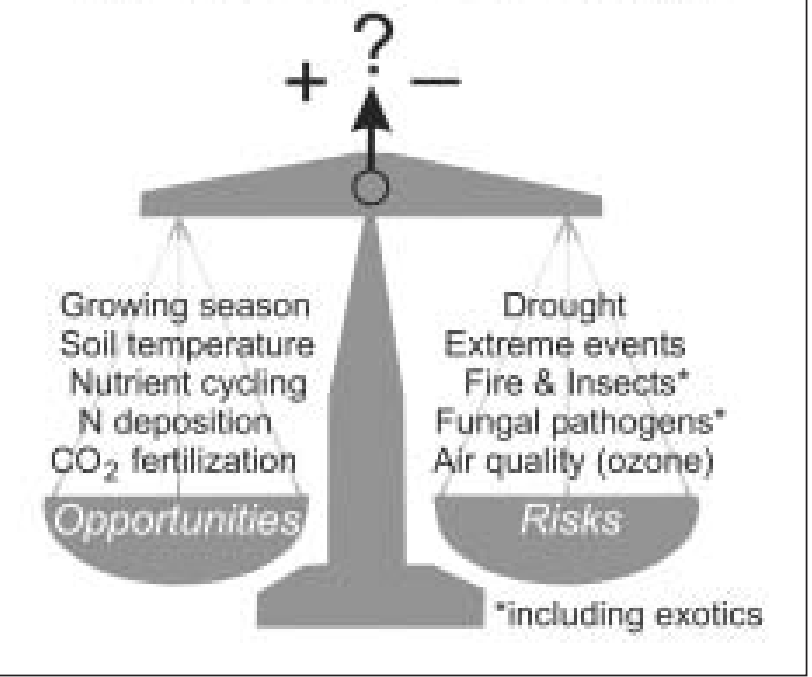

Fig. 1. Diagram summarizing major factors likely to affect productivity and biomass of northern forests under global climate change.

uncertainty arises from the difficulty in determining how the effects of positive and negative factors will balance in a given geographic area, as illustrated diagrammatically in Fig. 1.

On the one hand, climatic warming may be expected to benefit the productivity of forests, especially in cold climatic regions where the length of the growing season is limited by low temperatures. For example, warmer springs lead to earlier leaf-out of deciduous trees such as aspen, which leads to increased $\mathrm{CO}_{2}$ uptake and productivity (Barr et al. 2004). Further benefits may be expected owing to the role of $\mathrm{CO}_{2}$ in the photosynthesis of trees and other plants: as atmospheric $\mathrm{CO}_{2}$ concentrations increase, forest growth will tend to increase due to " $\mathrm{CO}_{2}$ fertilization," if other factors are not limiting. It has also been suggested that large-scale forest productivity has been significantly enhanced by human-induced increases in nitrogen (N) deposition (Chen et al. 2000), although such an increase has not been detected in the analysis of plot re-measurement data in the United States (Caspersen et al. 2000). The inclusion of these positive effects in global models has led to projections of increasing forest productivity and carbon sequestration over the next century, especially in northern forests (e.g., Cao and Woodward 1998). In a survey of 11 leading ecologists, most believed that standing biomass of northern forests was likely to increase under future climate change with a doubling of $\mathrm{CO}_{2}$ levels (Morgan et al. 2001). A global analysis of remote sensing measurements from 1981 to 1999 suggested that the global warming trend during this period had led to an overall "greening" of most northern areas, especially in Eurasia (Zhou et al. 2001).

On the other hand, however, there are a number of potentially negative factors, whose impacts are often difficult to predict. For example, recent results from an outdoor field experiment in the northern U.S. showed that the expected benefits of elevated $\mathrm{CO}_{2}$ on aspen growth were negated when 
Table 1. Summary of differences between the boreal forest versus parkland and prairie (after Hogg and Hurdle 1995). P refers to annual precipitation and PET is potential evapotranspiration, i.e., the expected amount of water that could be released to the atmosphere from a well-vegetated landscape when soil moisture is not limiting.

\begin{tabular}{llll}
\hline & Boreal forest & Parkland and Prairie & References \\
\hline Climate: & Moist (P > PET) & Dry (P < PET) & Hogg (1994, 1997) \\
Runoff: & Significant & Minimal in most years & see Hogg and Hurdle (1995) \\
Lake levels: & Stable & Variable & Campbell et al. (1994) \\
Wetlands: & Bogs and fens & Marshes and sloughs & Vitt et al. (2000) \\
Conifers: & Several species & Rare or absent & Hogg (1994) \\
Aspen: & Productive stands & Stunted patches & Hogg et al. (2005) \\
\hline
\end{tabular}

ground-level ozone was raised to the levels occurring in more polluted areas (Isebrands et al. 2001). Climate change also poses a risk of increasing impairment of forest productivity from outbreaks of insects and diseases (Volney and Fleming 2000, Volney and Hirsch 2005), including both native and exotic species (Krcmar-Nozic et al. 2000). Northern forests are also subject to damage by a wide variety of extreme climate events, notably wind (Peterson 2000), hail and ice storms (Hopkin et al. 2003), and thaw-freeze events during winter and spring (Auclair et al. 1996). Such extreme events are rarely included in forest productivity models, yet their combined impacts are expected to increase in the future under climate change (McCarthy et al. 2001). The most dramatic climate change impacts, however, are likely to occur in response to the projected increase in the extent, frequency and severity of drought and fire, especially in climatically dry regions such as the western Canadian interior.

\section{Forests on the Edge in Western Canada}

Much of the western Canadian interior is dominated by the boreal forest, a climatically cold forest type that extends across Canada from Yukon to Newfoundland. Despite its large size, the boreal forest has relatively few tree species, primarily black spruce (Picea mariana (Mill.) BSP), white spruce (Picea glauca (Moench) Voss), jack pine (Pinus banksiana Lamb.) and aspen (Populus tremuloides Michx.). In eastern Canada, the boreal forest forms its southern boundary with the temperate forest, where there are more than 50 species of trees, primarily deciduous hardwoods. The situation is very different in the west, where the boreal forest is bounded to the south by the aspen parkland, a primarily agricultural zone where forest cover is limited mainly to stunted patches of aspen interspersed by grasslands and croplands (Hogg and Hurdle 1995). South of the aspen parkland are the prairies, where trees are naturally absent except along major rivers. A parallel situation occurs in the more mountainous areas such as southern British Columbia, where the closed-canopy, cordilleran forests are bounded at the lower elevations by sparse woodlands of Douglas-fir (Pseudotsuga menziesii (Mirb.) Franco) or ponderosa pine (Pinus Ponderosa Dougl. ex Laws.), interspersed by bunchgrass and sagebrush (Meidinger and Pojar 1991). Thus, the forests of the western Canadian interior are potentially much more vulnerable than those in the east, if climate change leads to the northward (or upward) movement of prairie-like climates into existing forested areas.

In general, moisture is the most important factor governing the southern (or lower) range limits of forest cover in western Canada. In a previous study, Hogg (1994, 1997) found that the distribution of forests in the Prairie Provinces could be described remarkably well using the "zero-line" of a climate moisture index (CMI). The CMI is calculated as $\mathrm{P}$ minus PET, where $\mathrm{P}$ is the yearly average precipitation (input of water to the landscape by rain and snow melt), and PET is yearly potential evapotranspiration, both expressed in centimetres of water per year. PET is defined as the estimated loss of water vapour from healthy, productive vegetation on soils with adequate soil moisture. Values of PET are estimated using simple equations that use either a combination of longterm monthly temperature and solar radiation data (JensenHaise method, see Hogg 1994) or temperature data alone (simplified Penman-Monteith method, Hogg 1997). In general, continuous forests are limited to the areas with moist climates, where $\mathrm{P}$ is greater than PET (i.e., positive CMI values). In contrast, the aspen parkland and prairies occupy the drier areas where $\mathrm{P}$ is less than PET (i.e., negative CMI values). In hilly or mountainous areas, conditions are generally wetter at the higher elevations, because precipitation amounts are greater whereas the cooler temperatures lead to smaller rates of potential water loss (PET).

In the forested areas with positive CMI values, there is significant surplus moisture during most years that drains off the landscape as water runoff into streams and rivers. This leads to relatively constant water levels in lakes (Campbell et al. 1994), and the high water table allows the formation of peatlands (bogs and fens, also known locally as "muskeg"). Peatlands depend on a consistent water level in the soil close to the surface to maintain the oxygen-free conditions that slow down the rate of decay so that the peat can accumulate.

In the parklands and grasslands, however, virtually all aspects of the ecosystem are changed because of the dry climate (Table 1). There is little surplus moisture, so that there are very few streams, while lakes are often saline and may dry up completely during periods of drought. Coniferous trees are naturally absent, except for occasional white spruce stands along the more shaded, north-facing slopes of major river valleys, or at high-elevation sites such as the "island forests" of the Cypress Hills (Hogg 1994, Henderson et al. 2002).

There are major differences among species of trees in the region that largely determine their distribution and productivity across the landscape. These include differences in mode of regeneration, leaf longevity (e.g., deciduous versus evergreen), shade tolerance, responses to soil conditions, and susceptibility to defoliation or damage by specific insects and diseases. Despite these differences, however, there can be remarkable similarity among tree species in terms of their 
year-to-year growth responses to climate variation. This is especially true in the drier forested areas of western Canada, where tree-ring studies have shown similar positive relationships between stem growth and precipitation in several species at many locations, including white spruce and aspen in southwestern Yukon (Hogg and Wein 2005), white spruce and bur oak (Quercus macrocarpa Michx.) in southern Manitoba (Chhin et al. 2004, St. George and Nielsen 2002), Douglas-fir and ponderosa pine in British Columbia (Watson and Luckman 2001), and limber pine (Pinus flexilis James) in southwestern Alberta (Case and MacDonald 1995). A treering study of 72 aspen stands across western Canada (Hogg et al. 2005) showed that regional stem growth of this species is governed mainly by drought and insect defoliation, and that average stand-level biomass of aspen stands in the parkland zone was $37 \%$ less than in comparable stands in the boreal forest.

On the other hand, tree-ring studies of forests at higher elevations or at northern tree-line sites in the region commonly show positive growth responses to temperature (e.g., St. George and Luckman 2001). Forests on poorly drained sites such as peatlands also show increases in growth responses several years after water tables are lowered (Dang and Lieffers 1989), suggesting that periods of drought might be beneficial to forest productivity in some situations. In a recent study of three commercially important conifers across the British Columbia interior, Nigh et al. (2004) found that site index was positively related to both temperature and moisture, and predicted that stand productivity of all three species would likely increase under future climatic warming. There are indications that climatic warming may already be promoting forest productivity in some areas. Dempster (2004) reported that there has been a steady increase in the site index of lodgepole pine (Pinus contorta Dougl. ex Loud.) in the foothills of western Alberta over the past century, although other management-related factors may also explain this increase.

More comprehensive studies would be needed to determine how climate variation affects the growth of the region's forests as a whole. However, the evidence to date suggests that drought is the most important climatic factor causing reduced stand-level growth and dieback in most of the managed forests in the region, which are located mainly in the more southerly forested areas at relatively low elevation.

Upland species of conifers such as white spruce are highly drought-tolerant, as demonstrated by their survival as mature, planted trees in numerous farm shelter-belts and block plantings on the Canadian prairies and parklands. Surveys of plantations in the region by Hogg and Schwarz (1997) showed that planted white spruce produces abundant natural regeneration on cleared farmlands in the boreal forest, but almost no regeneration at comparable sites in the dry southern parkland and grassland zones. The main reason for this appears to be that conifer seedling establishment requires a sustained period when soils are moist-a rare occurrence under a prairie-like climate. Such prairie-like conditions occur even in some northern areas with permafrost, such as the valleys of southwestern Yukon, where white spruce has shown very poor regeneration following fire in some areas (Hogg and Wein 2005).
Like other poplars, aspen has the ability to resprout from its roots after the aboveground stems are killed by fire or drought, which may explain why its distribution extends further south than that of the boreal conifers (Hogg 1994). However, aspen is prone to periodic episodes of crown dieback following periods of drought, especially in combination with other stressors such as spring thaw-freeze events, insect defoliation and fungal pathogens (Hogg et al. 2002, Frey et al. 2004).

\section{Potential Impacts of Drought under a Changing Climate}

In view of the above, it appears that the most critical issue for the future functioning of forested ecosystems in this region is whether conditions will become drier under climate change, and how these drier conditions may affect growth and disturbance regimes. Most of the computer models of global climate change (these models are called General Circulation Models or GCMs) agree that there will be significant warming, but there are greater uncertainties in their predictions of future changes in moisture regimes. Even if precipitation amounts increase slightly, however, conditions may become drier because the warmer temperatures lead to increased PET. For example, Hogg and Hurdle (1995) showed that under a future climate scenario with a projected $11 \%$ increase in $\mathrm{P}$ and a warming of $4-5^{\circ} \mathrm{C}$, conditions would become much drier in the western Canadian interior, based on decreasing values of the CMI. The maps from this early analysis showed that CMI values would become negative across large areas of the western boreal forest, reflecting dry conditions similar to those of the present aspen parkland zone. The results of a similar analysis is shown in Fig. 2, that is based on a more recent GCM scenario (GCGM2 A21, see Henderson et al. 2002) and a more sophisticated method of climate interpolation with a $10-\mathrm{km}$ resolution digital elevation model (Price et al. 2000). Under the projected climate for the period 2041-2070, the CMI “zero-line" moves northward, giving negative CMI values in the southernmost portions of the western boreal forest. Negative CMI values also develop at the lower elevations along the rivers and major lakes of northern Alberta and adjacent Northwest Territories (Fig. 2), as well as across parts of southwestern Yukon and Alaska (not shown). There is also a significant expansion of the area with negative CMI values in the British Columbia interior. Based on the analysis, these are the forested areas that are most vulnerable to the impact of climate change-induced drought stress over the next few decades, prior to the maturation of the forests being replanted today.

Under the projected changes in climate for 2041-2070, virtually all aspects of ecosystem functioning (Table 1) would be impacted in these vulnerable areas (Fig. 2). Lakes, wetlands and peatlands would be profoundly affected, and forest productivity could be greatly reduced, especially following periods of drought-induced dieback and mortality, or when conifers fail to regenerate naturally after disturbances such as fire. Drought-stressed forests are also likely to become more susceptible to damage by insects and diseases, especially those whose life cycles are favoured by warmer temperatures (Volney and Hirsch 2005). 


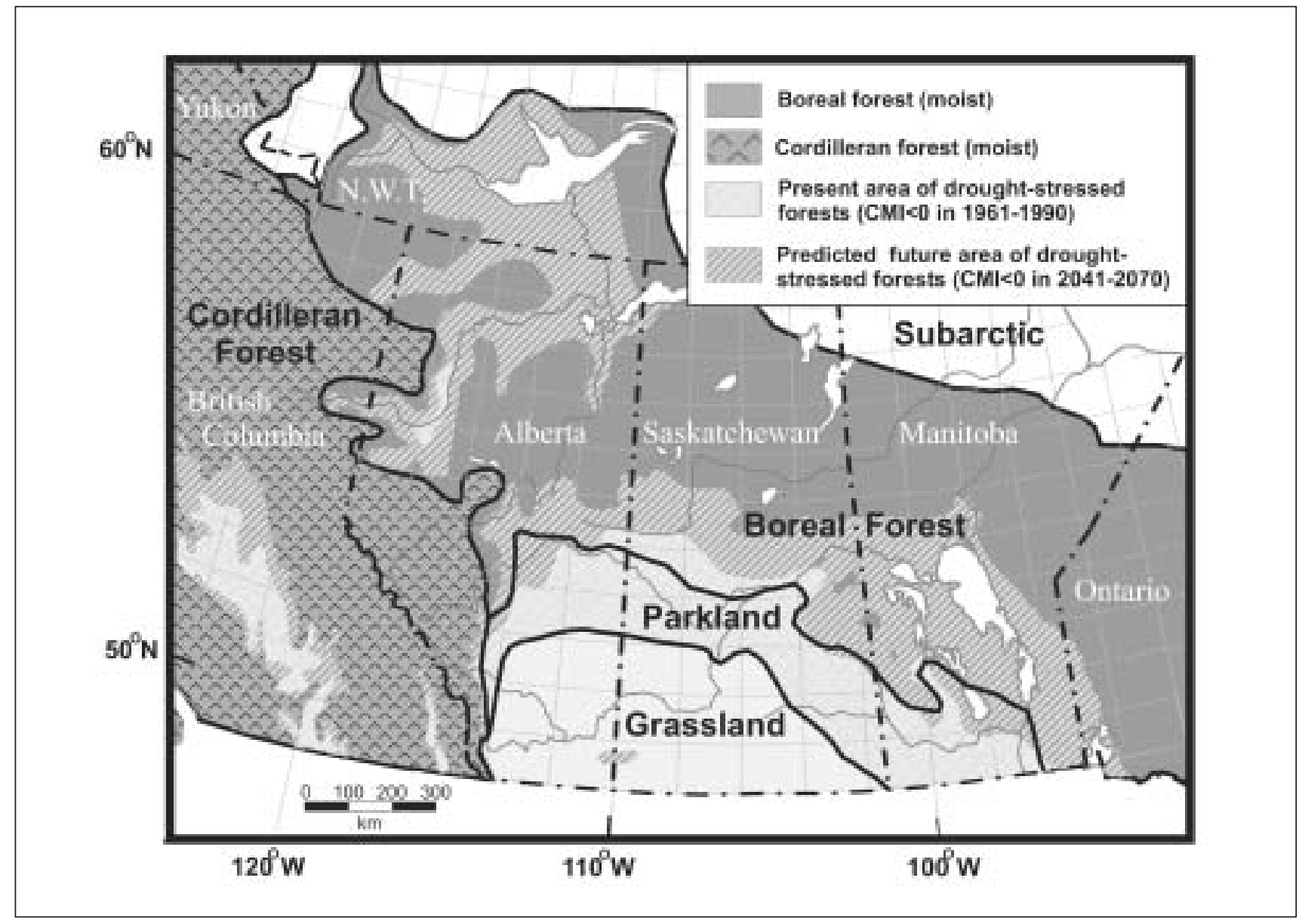

Fig. 2. Map of the western Canadian interior showing major vegetation zones and the area of drought-stressed forests under the observed recent climate (period 1961-1990) and under a projected scenario of future climate (period 2041-2070). Drought-stressed forests were defined as those areas with negative values of the Climate Moisture Index (Hogg 1997), where average annual precipitation is insufficient to meet the potential water demands (evapotranspiration) of productive forests on a well-vegetated landscape (see text].

Although drought is the primary mechanism acting to constrain growth and distribution of trees in a water-limited landscape, fire is one agent by which change may take place rapidly at the landscape level. Across Canada, the composition of the boreal forest is already shaped by the fire regime with the gradual decrease in the abundance of fire-intolerant balsam fir (Abies balsamea (L.) Mill.) from the wet eastern boreal forest, to the much drier western boreal forest. Flannigan et al. (2001) have estimated that over the next century, fire activity will increase across the western boreal forest. Although many of the major conifers (e.g., black spruce, lodgepole pine and jack pine) are adapted to reproduce following fire, their successful regeneration depends on the presence of cone-bearing trees. A future increase in fire frequency translates into an increase in the area over which the fire return interval becomes shorter than the time for seedlings to reach sexual maturity. We can therefore expect an increase in the dominance of aspen in the most fire-prone regions, even if there is sufficient soil moisture for conifer seedlings to survive.

In the long term, an increased probability of fire losses has important implications for the estimation of annual allow- able cuts, in which timber supplies are often projected two rotations into the future. Furthermore, the likelihood of a fire-induced shifting of natural vegetation from conifers to aspen or even grassland should be considered when projecting future changes at the landscape level, especially in the more drought-prone areas identified in Fig. 2.

Although climate change clearly poses a serious risk to future forest productivity in the region, some of the negative impacts will likely be offset by the benefits of longer growing seasons, warmer soils and $\mathrm{CO}_{2}$ fertilization. Also, even in the most vulnerable areas, there is a wide variety of potential human actions that could reduce the risks of negative impacts and, in some instances, derive benefits from the opportunities that global change may provide from a forestry perspective.

\section{Human Actions - Mitigation and Adaptation}

There are two broad categories of human actions that can be identified in response to climate change. The first is mitigation, which refers to human actions aimed at slowing down the rate of climate change, primarily through their effects on global atmospheric $\mathrm{CO}_{2}$ concentrations. These actions 
include reductions in $\mathrm{CO}_{2}$ emissions from fossil fuel emissions and land use changes, as well as the implementation of forest management practices such as afforestation to enhance carbon storage within forested ecosystems on the landscape. In general, the ultimate effectiveness of these mitigative measures depends on international coordination through agreements such as the Kyoto Protocol (Watson et al. 2000), because of course, $\mathrm{CO}_{2}$ knows no political boundaries as it circulates globally in the earth's atmosphere.

The second category of human actions is adaptation, which refers mainly to local activities that are taken to minimize the negative impacts of climate change, and to realize the potential benefits. In some cases, there is overlap between adaptation and mitigation, especially in the forestry sector where maximizing the local commodity of interest (tree growth and wood fibre) can also serve to maximize carbon uptake and storage. Climate change adaptation is increasingly being recognized as a major issue for the Canadian forestry sector, and several approaches have been presented in recent reviews on this topic (e.g., Papadopol 2000, Spittlehouse and Stewart 2003, Spittlehouse 2005), including a structured, decision-making framework that starts with an examination of present climate vulnerabilities (Ohlson et al. 2005). These approaches are relevant to forest management adaptation in the western Canadian interior, especially those that address the potential impacts of a drier future climate and associated increases in fire and pest damage. Some of the stand-level measures that have been proposed for adaptation to drought include reforestation with drought-tolerant provenances from more southerly or low-elevation areas, and precommercial thinning of stands to conserve soil moisture (see Papadopol 2000, Spittlehouse and Stewart 2003). Also, seedling survival could be enhanced in climatically dry areas by planting larger stock, scheduling reforestation activities for the wettest periods, or by applying alternative measures such as partial cutting to ameliorate seedling microclimate (Man and Lieffers 1999). Where droughts become severe enough to cause large-scale tree mortality, an increased reliance on fibre from salvage logging might also be considered as a fallback option.

Another option is the "human-assisted migration" of drought-tolerant trees (e.g., ponderosa pine) through artificial regeneration, especially in situations where the climate becomes too dry for the existing tree species to survive. The introduction of non-native trees may pose many questions and concerns, especially in parks and protected areas (Scott and Lemieux 2005). These concerns, however, may need to be weighed against the impacts of human-induced global change, including the potential elimination of forest cover from the driest areas such as the island forests of the Great Plains (Henderson et al. 2002).

Climate drives forest growth, and forest growth drives timber supply models. One early adaptation action will be to recognize the changes in growth and the uncertainties associated with climate change and explicitly incorporate those in models used for long-term forest management planning. Without such changes, planning will be made as if historical climate conditions that prevailed during the life of trees, as used to parameterize existing growth and yield models, will still prevail in the future. Ung et al (2001) have shown that climate-based site index could successfully replace phytometric site index in volume predictions for shade-intolerant species such as jack pine and aspen. Johnston and Williamson (2005) have estimated the effect of projected climate on the yield of white spruce in Saskatchewan, and computed Soil Expectation Values for various drought and fire scenarios. Such accounting of climate change impacts and increased uncertainties will also have to be included in strategic planning.

While the climate models may agree about general global trends in warming and drying, we need to recognize that there are still great uncertainties for the future. For example, GCMs do not generally capture extreme climate events such as extreme winter cold, thaw-freeze or wind storms. There are also uncertainties as to how future changes in climate will influence the threat of insects and diseases, including exotics, to plantations and natural forests. Thus, prudent strategies for maintaining and enhancing future forest productivity should be aimed not only at taking advantage of better growing conditions, but also at reducing the risks associated with particular threats to forest productivity and health.

Among these strategies, the least controversial include the establishment, monitoring and analysis of operational trials with mixed provenances of a given native tree species, or mixtures of native tree species within the same plantation. In the most drought-sensitive areas of the managed forest, however, it may also be prudent to begin considering more unconventional alternatives such as human-assisted movement of tree species and genotypes from more southerly, semi-arid areas. Adopting a diversity of forest management strategies at the landscape and regional levels could also be helpful in reducing the risk of large-scale impacts, given the uncertainties. Finally, new approaches to forest management and reforestation will often require economic analyses, public consultations and biological research (e.g., on risks related to forest pests), along with the development of alternative methods for harvesting and processing to see which could be commercially viable.

Now that climate change is upon us, it is timely to start testing these alternative approaches and monitoring successes and failures. In addition, we need to establish and maintain regional, national and international monitoring networks or programs capable of early detection of changes in the forest over large areas (McCarthy et al. 2001). In Canada, these could build on the existing plot-based networks being managed by federal and provincial governments, the forest industry, and other agencies. There is also a need for a stronger coupling of plot-based monitoring programs with remote sensing and large-scale modelling. Key indicators of change should be developed and monitored more closely, including landscape-level measures such as forest fragmentation and changes in radial growth based on periodic analyses of treerings across climate gradients and over large areas. Monitoring of these trends in climatically sensitive areas such as the boreal-tundra and prairie-boreal ecotones could provide particularly useful indicators of change, as would the growth of long-lived tree species in marginal forest environments such as bogs or rocky outcrops. Data will need to be pooled across land units and spatial scales, and across disciplines, to provide the managers and decision-makers a picture of both national and regional changes and risks. Good monitoring coupled with advanced planning and forecasting are key components of successful adaptation strategies. 


\section{Acknowledgements}

We thank V.J. Lieffers, W.J.A. Volney and D.T. Price for helpful comments on the manuscript, and we also thank our colleagues and collaborators for their insights and useful discussions on this topic. We gratefully acknowledge the role of D. McKenney, D.T. Price and M. Siltanen in providing the gridded climate information required for the figure showing the extent of drought-stressed forests in western Canada under both current and projected future climates.

\section{References}

Auclair, A.N.D., J.T. Lill and C. Revenga. C. 1996. The role of climate variability and global warming in the dieback of northern hardwoods. Water Air Soil Pollut. 91: 163-186.

Barr, A.G., T.A. Black, E.H. Hogg, N. Kljun, K. Morgenstern and Z. Nesic. 2004. Inter-annual variability in the leaf area index of a boreal aspen-hazelnut forest in relation to net ecosystem production. Agric. For. Meteorol. 126: 237-255.

Betts, R.A. 2000. Offset of the potential carbon sink from boreal forestation by decreases in surface albedo. Nature 408: 187-190.

Camill, P. 2005. Permafrost thaw accelerates in boreal peatlands during late-20th century climate warming. Climatic Change 68: 135-152.

Campbell, C., I.D. Campbell and E.H. Hogg. 1994. Lake area variability across a climatic and vegetational transect in southeastern Alberta, Canada. Geogr. Phys. Quatern. 48: 207-212.

Cao, M. and F.I. Woodward. 1998. Net primary and ecosystem production and carbon stocks of terrestrial ecosystems and their responses to climate change. Global Change Biol. 4: 185-198.

Case, R.A. and G.M. MacDonald. 1995. A dendroclimatic reconstruction of annual precipitation on the western Canadian prairies since A.D. 1505 from Pinus flexilis James. Quatern. Res. 44: 267-275. Caspersen, J.P., S.W. Pacala, J.C. Jenkins, G.C. Hurtt, P.R. Moorcroft and R.A. Birdsey. 2000. Contributions of land-use history to carbon accumulation in U.S. forests. Science 290: 1148-1151.

Chen, W., J. Chen and J. Cihlar. 2000. An integrated terrestrial carbon-budget model based on changes in disturbance, climate, and atmospheric chemistry. Ecol. Modell. 135: 55-79.

Chhin, S., G.G. Wang and J. Tardif. 2004. Dendroclimatic analysis of white spruce at its southern limit of distribution in the Spruce Woods Provincial Park, Manitoba, Canada. Tree-Ring Res. 60: 31-43.

Dang, Q.L. and V.J. Lieffers. 1989. Assessment of patterns of response of tree ring growth of black spruce following peatland drainage. Can. J. For. Res. 19: 924-929.

Dempster, W.R. 2004. Comparison of pre-harvest and post-harvest site indices. Technical Report, Foothills Growth and Yield Association Regenerated Lodgepole Pine Project. 22 p. Web site at http://www.fmf.ca/FGYA/FGYA_Tr6.pdf (accessed 8 June 2005).

Environment Canada. 2004. Climate trends and variations bulletin, annual 2003, regional temperature. Web site at www.mscsmc.ec.gc.ca/ccrm/bulletin/annual03/regional_e.cfm (accessed 13 September 2004).

Flannigan, M., I. Campbell, M. Wotton, C. Carcaillet, P. Richard and Y. Bergeron. 2001. Future fire in Canada's boreal forest: paleoecology results and general circulation model - regional climate model simulations. Can. J. For. Res. 31: 854-864.

Frey, B.R., V.J. Lieffers, E.H. Hogg and S.M. Landhäusser. 2004. Predicting landscape patterns of aspen dieback: mechanisms and knowledge gaps. Can. J. For. Res. 34: 1379-1390.

Henderson, N., E.H. Hogg, E. Barrow and B. Dolter. 2002. Climate change impacts on the island forests of the Great Plains and the implications for nature conservation policy. Prairie Adaptation Research Collaborative (PARC), Regina, SK.

Hogg, E.H. 1994. Climate and the southern limit of the western Canadian boreal forest. Can. J. For. Res. 24: 1835-1845.
Hogg, E.H. 1997. Temporal scaling of moisture and the forest-grassland boundary in western Canada. Agric. For. Meteorol. 84: $115-122$.

Hogg, E.H. and P.A. Hurdle. 1995. The aspen parkland in western Canada: A dry-climate analogue for the future boreal forest? Water Air Soil Pollut. 82: 391-400.

Hogg, E.H. and A.G. Schwarz. 1997. Regeneration of planted conifers across climatic moisture gradients on the Canadian prairies: implications for distribution and climate change. J. Biogeogr. 24: 527-534.

Hogg, E.H. and R.W. Wein. 2005. Impacts of drought on forest growth and regeneration following fire in southwestern Yukon, Canada. Can. J. For. Res. (in press).

Hogg, E.H., J.P. Brandt and B. Kochtubajda. 2002. Growth and dieback of aspen forests in northwestern Alberta, Canada, in relation to climate and insects. Can. J. For. Res. 32: 823-832.

Hogg, E.H., J.P. Brandt and B. Kochtubajda. 2005. Factors affecting interannual variation in growth of western Canadian aspen forests during 1951-2000. Can. J. For. Res. 35: 610-622.

Hogg, E.H., D.T. Price and T.A. Black. 2000. Postulated feedbacks of deciduous forest phenology on seasonal climate patterns in the western Canadian interior. J. Climate 13: 4229-4243.

Hopkin, A., T. Williams, R. Sajan, J. Pedlar and C. Nielsen. 2003. Ice storm damage to eastern Ontario forests: 1998-2001. For. Chron. 79: 47-53.

Houghton, J.T., Y. Ding, D.J. Griggs, M. Noguer, P.J. van der Linden and D. Xiaosu (eds.). 2001. Climate change 2001: The scientific basis. Intergovernmental Panel on Climate Change (IPCC) Third Assessment Report. Cambridge University Press, UK.

Isebrands, J.G., E.P. McDonald, E. Kruger, G. Hendrey, K. Percy, K. Pregitzer, J. Sober and D.F. Karnosky. 2001. Growth responses of Populus tremuloides clones to interacting elevated carbon dioxide and tropospheric ozone. Environ. Pollut. 115: 359-371.

Johnston, M. and T. Williamson. 2005. Climate change implications for stand yields and Soil Expectation Values: A northern Saskatchewan case study. For. Chron. 81(5): 683-690.

Krcmar-Nozic, E., B. Wilson and L. Arthur. 2000. The potential impacts of exotic forest pests in North America: a synthesis of research. Natural Resources Canada, Canadian Forest Service, Pacific Forestry Centre, Victoria, BC. Information Report BC-X-387, ix + 33 p. Kurz, W.A. and M.J. Apps, 1999. A 70-year retrospective analysis of carbon fluxes in the Canadian forest sector. Ecol. Appl. 9: 526-547. Man, R. and V.J. Lieffers. 1999. Effects of shelterwood and site preparation on microclimate and establishment of white spruce seedlings in a boreal mixedwood forest. For. Chron. 75: 837-844.

McCarthy, J.J., O.F. Canziani, N.A. Leary, D.J. Dokken and K.S. White (eds.). 2001. Climate change 2001: Impacts, adaptation and vulnerability. Intergovernmental Panel on Climate Change (IPCC) Third Assessment Report. Cambridge University Press, UK. Meidinger, D. and J. Pojar (eds.). 1991. Ecosystems of British Columbia. B.C. Min. For. Special Report Series No. 6.330 p. Web site at www.for.gov.bc.ca/hfd/pubs/Docs/Srs/Srseries.htm (accessed 8 June 2005).

Morgan, M.G., L.F. Pitelka and E. Sheviakova. 2001. Elicitation of expert judgments of climate change impacts on forest ecosystems. Climatic Change 49: 279-307.

National Climatic Data Centre. 2005. The climate of 2004. Web site at http://lwf.ncdc.noaa.gov/oa/climate/research/2004/ann/global. html (accessed 3 May 2005).

Nigh, G.D., C.C. Ying and H. Qian. 2004. Climate and productivity of major conifer species in the interior of British Columbia. For. Sci. 50: 659-671.

Ohlson, D.W., G.A. McKinnon and K.G. Hirsch. 2005. A structured decision-making approach to climate change adaptation in the forest sector. For. Chron. 81: 672-677.

Papadopol, C.S. 2000. Impacts of climate warming on forests in Ontario: options for adaptation and mitigation. For. Chron. 76: 139-149. 
Peterson, C.J. 2000. Catastrophic wind damage to North American forests and the potential impact of climate change. Sci. Total Environ. 262: 287-311.

Pielke, R.A., R. Avissar, M. Raupach, H. Dolman, X. Zeng and S. Denning. 1998. Interactions between the atmosphere and terrestrial ecosystems: influence on weather and climate. Global Change Biol. 4: 461-475.

Price, D., D.W. McKenney, I. Nalder, M.F. Hutchinson and J. Kestevan, J. 2000. A comparison of two statistical methods for interpolating monthly mean climate. Agric. For. Meteorol. 101:81-94.

Saporta, R., J.R. Malcolm and D.L. Martell. 1998. Chapter 6: The impact of climate change on Canadian forests. In G. Koshida and W. Avis (eds.). The Canada Country Study: Climate Impacts and Adaptation. National Sectoral Volume. pp. 319-392. Environment Canada Cat. No. En56-119/6-1997E, Ottawa, ON.

Scott, D. and C. Lemieux. 2005. Climate change and protected area policy and planning in Canada. For. Chron. 81(5): 696-703.

Shugart, H., R. Sedjo, and B. Sohngen. 2003. Forests and global climate change: Potential impacts on U.S. forest resources. Pew Center on Global Climate Change, Arlington VA.

Spittlehouse, D.L. 2005. Integrating climate change adaptation into forest management. For. Chron. 81(5): 691-695.

Spittlehouse, D.L. and R.B. Stewart. 2003. Adaptation to climate change in forest management. BC Journal of Ecosystems and Management 4(1): 1-11.

St. George, S. and B.H. Luckman. 2001. Extracting a paleotemperature record from Picea engelmannii tree-line sites in the central Canadian Rockies. Can. J. For. Res. 31: 457-470.
St. George, S. and E. Nielsen. 2002. Hydroclimatic change in southern Manitoba since A.D. 1409 inferred from tree rings. Quatern. Res. 58: $103-111$.

Ung, C.H., P. Y. Bernier, F. Raulier, R.A. Fournier, M.-C. Lambert and J. Régnière. 2001. Biophysical site indices for shade tolerant and intolerant boreal species. For. Sci. 47: 83-95.

Volney, W.J.A. and R.A. Fleming. 2000. Climate change and impacts of boreal forest insects. Agric. Ecosyst. Environ. 82: 283-294.

Volney, W.J.A. and K.G. Hirsch. 2005. Disturbing forest disturbances. For. Chron. 81 (5): 662-668.

Vitt, D.H., L.A. Halsey, I.E. Bauer and C. Campbell. 2000. Spatial and temporal trends in carbon storage of peatlands of continental western Canada through the Holocene. Can. J. Earth Sci. 37: 683-693.

Watson, E. and B.H. Luckman. 2001. Dendroclimatic reconstruction of precipitation for sites in the southern Canadian Rockies. The Holocene 11: 203-213.

Watson, R.T., I.R. Novel, N.H. Bolin, N.H. Ravindranath, D.J. Veraro and D.J. Dokken (eds.). 2000. Land use, land-use change, and forestry. Intergovernmental Panel on Climate Change (IPCC) Special Report. Cambridge University Press, New York.

Zhou, L., C.J. Tucker, R.K. Kaufmann, D. Slayback, N.V. Shabanov and R.B. Myneni. 2001. Variations in northern vegetation activity inferred from satellite data of vegetation index during 1981 to 1999. J. Geophys. Res. 106 (D17): 20069-20083. 